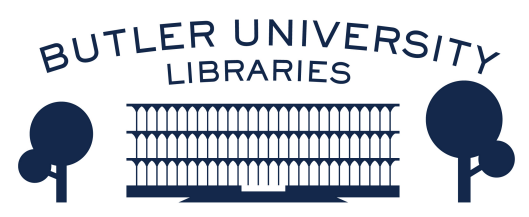

Journal of Hindu-Christian Studies

Volume 18

Article 15

January 2005

\title{
Book Review: "A History of Modern Yoga: Patanjali and Western Esotericism"
}

Harold Coward

Follow this and additional works at: https://digitalcommons.butler.edu/jhcs

Part of the Religion Commons

\section{Recommended Citation}

Coward, Harold (2005) "Book Review: "A History of Modern Yoga: Patanjali and Western Esotericism"," Journal of Hindu-Christian Studies: Vol. 18, Article 15.

Available at: https://doi.org/10.7825/2164-6279.1348

The Journal of Hindu-Christian Studies is a publication of the Society for Hindu-Christian Studies. The digital version is made available by Digital Commons @ Butler University. For questions about the Journal or the Society, please contact cbauman@butler.edu. For more information about Digital Commons @ Butler University, please contact digitalscholarship@butler.edu. 
and the bhaktas are all longing for the grace of the Lord Siva.

Another curious term used by the authors here in the Saiva context is sorcery or black magic. They find a Sanskrit term "abhicara" for it and the Kanta Purnaa text refers to it as "velvi" (p.88). The use of the term "sorcery" with all its negative connotations in the context of the Daruvana episode is rather misleading. The traditional understanding of the yogic powers which are creative and Siva's creative power to transform all obstacles are not sorcery. It is not clear why the authors hesitate to call it "miraculous power", a term well known in the religious literature of the world. Sorcery, witchcraft and "pillicunyam" (Tamil equivalent), terms which would sound very odd in the Judeo-Christian context, have their own logic and ontology, as the authors point out (p.90). But then what they describe after that is the creative process of phenomenal éxistence and the formation of the individual consciousness. Yet one wonders how this analysis fits into the visit of Siva to the pine forest.

It may be true that the Saiva theologians' conceptual world is rigid, static, strangely idealistic. But then they are not used to interacting with process theologians. Perhaps an initiation into process theism might bring some fresh thinking to the Saiva worldview. However the standard objections of the Christian theologians to this approach will hold good also for the Saiva understanding of the divine. A statement like this: Siva "though omniscient, there are many things he does not know - everything that has to do with non-sentient phenomena for example," (p.200) would also imply a limited understanding of God's transcendence.

The authors' effort to get at this Daruvana episode by way of process theism requires careful study and theological insight. I hope this publication invites Saivite thinkers to respond to this type of theological interpretation and look at their own tradition from a new angle, even if they do not accept it fully. Such an intercultural exchange would be fruitful to both sides of the dialogue. Otherwise the Siva episodes will remain mere stories in calendar art and repeated with usual clichés without enriching the tradition.

Anand Amaladass Chennai

\section{A History of Modern Yoga: Patanjali and Western Esotericism. Elizabeth De Michelis. New York: Continuum, 2004, xvii + 282}

pp.

IN his important book, The Limits of Scripture, Anantanand Rambachan distinguishes between Sankara and Vivekananda on the authority of the Vedas and its relationship to anubhava or personal experience. Now in her $A$ History of Modern Yoga, De Michelis shows how a similar distinction obtains between Patanjali's Yoga Sutras and Vivekananda's Raja Yoga. Further, she demonstrates how this reinterpretation of Yoga by Vivekananda depends on Keshubchandra Sen's earlier "revivalistic reinterpretation" of Yoga (p. 84) and how Vivekananda's Raja Yoga is foundational for the various developments of Modern Yoga which take place in the English-speaking world during the twentieth century. A historical analysis and "Typology of Modern Yoga" is developed, and as a criterion example of Modern Yoga, a detailed case study of the theory and practice of lyengar Yoga is offered.

All of this is most helpful in allowing one to sort out and understand the plethora of Modern Yoga schools, 
movements and gurus which have arisen in India, UK and America since Vivekananda's appearance at the Chicago Parliament of Religions in 1893. Unexpected connections with Theosophy, Mesmerism, New Age Religion, the Psychology of William James, Krishnamurti and others are revealed in this fine piece of careful scholarly analysis. In the end the relationship between Patanjali's Yoga Sutras and Modern Yoga is shown to be increasingly remote. Rather than Patanjali's mental emphasis grounded in Sankhya metaphysics, much Modern Yoga is shown to focus on physical practices (yogic poses or asanas and yogic breathing or pranayama) with a neo-Vedanta kind of individual "self-realization" or anubhava experience being emphasized. Indeed, concludes De Michelis, "Within the conceptual universe of Modern Y Yoga, the Sutras find themselves demoted to representing only a very limited range of (usually occultized) hathayogic practices" (p.180).

The book begins by tracing the historical and intellectual roots of Modern Yoga through the Western philosophical and Christian influences upon Rammohun Roy, Debendranath Tagore and Keshubchandra Sen as foundational for Vivekananda and his reinterpretation of Patanjali's Yoga. This forms Part I of the book and depends to a large extent on the earlier studies of scholars such as Knof, Halbfass and Rambachan. Part II shows how this Neo Vedanta reinterpretation of "God realization" and "Self-realization" sets the stage for Vivekananda's basic formulation of Modern Yoga in his publication Raja Yoga, in 1896, based on lectures delivered in America shortly after the Chicago Parliament of Religions. This was a time in the West of strong cravings for spiritual practices. As De Michelis puts it, in an age of swift technological growth, secularization and utilitarianism, people wanted techniques to achieve immediate practical and rational/scientific goals. Vivekananda responded by following the approach he had learned as a young man sitting at Sen's feet (rather than Ramakrishna who is usually identified as Vivekananda's guru) and reinterpreting classical Yoga. Relying on his own inspiration and his understanding of the mind-set of his Western listeners, Vivekananda focused on the practice section of the Yoga Sutras (the so-called astangayoga). $\mathrm{He}$ also drew from hathayogic teachings regarding yoga poses, and mesmeric beliefs (popular in North America at that time) in relation to the power of prana or yogic breathing as practical techniques to speed up one's spiritual progress. In lecturing on Patanjali's Samadhi or meditative states, Vivekananda makes use of the then popular Functional Psychology of William James, with whom he became acquainted during this stay in Boston (p.171), and the earlier theosophist writers, Blavatsky and Judge, who distinguish the term raja yoga (the mental aspects) from hatha yoga (the physical aspects) as both being present in Patanjali's Yoga Sutras. It is Judge who explicitly identifies raja yoga with the classic yogascittavrttinirodhah formulation "of Patanjali (Yoga Sutras 1.2). De Michelis concludes her analysis as follows: "The misidentification between Vivekananda's raja yoga and the Yoga Sutras of Patanjali ... betrays a cognitive confusion which causes a typically esoteric variety of yoga ... to be understood ... as the most important and universally applicable form of yoga" (p.279). Yet this misidentification of raja yoga and the Yoga Sutras is appropriated from Vivekananda into most forms of Modern Yoga.

Having exposed the intellectual root of Modern Yoga as Vivekananda's 1896 book on Raja Yoga, De Michelis goes on to trace twentieth-century developments. There is "Modern Psychosomatic Yoga" with its focus on practice and a privatized religious/cultic milieu as exemplified by Sivananda and his disciples or Swami Rama and his Himalayan Institute. Arising out of this approach come two others: "Modern Postural Yoga" and "Modern Meditational Yoga." According to the author, "Modern Postural Yoga" places a greater stress on physical practices as seen in Iyengar Yoga 
and Astanga Yoga. In contrast, "Modern Meditational Yoga" puts more stress on mental practices such as is seen in early TM, Sri Chinmoy and some modern Buddhist groups. A chart outlining this typology is offered on p.188 and will be very helpful for teaching purposes. A separate offshoot is called "Modern Denominational Yoga" by the author. It is characterized by a focus on Neo-gurus and on the school's own teachings which are given authoritative status. Examples include the Brahma Kumaris, Sahaja Yoga, ISKCON, and late TM. After establishing her typology of Modern Yoga groups, the author identifies three developmental phases: popularization (1950s to mid-1970s), consolidation (mid1970 s to late $1980 \mathrm{~s}$ ) and acculturation (late 1980 s to the present). These phases are described and discussed mainly with reference to the longer established Postural Yoga schools in the UK. There has been an increase of those practicing postural yoga of about 300 percent from 1970 to 1993 when those attending classes in Britain are numbered at 120,000 and its popularity continues to grow.

The last fifty pages of the book present a case study of one such school, namely the Iyengar School of Modern Postural Yogas, which it is claimed is the most influential and widespread of all the postural schools. The author successfully employs her own typology (described above) to analyze the theory and practice of the Iyengar School of Modern Yoga.

This carefully researched and well written book fills in an important gap in knowledge - how we got from the classical school based on Patanjali's Yoga Sutras to the modern forms of yoga that we encounter in community recreation centers, college adult education programs and in popular books. As a scholar who has carefully studied Patanjali's Yoga Sutras (with my teacher, T.R.V. Murti) and published on them (e.g., Yoga and Psychology (SUNY Press, 2002), I have always been puzzled by the modern practitioners who often cite the Yoga Sutras but are so different. Thanks to this book, I, and my students, have a much better understanding and a sound basis for further study.

\author{
Harold Coward \\ University of Victoria
}

\section{In Search of Identity: Debates on Religious Conversion in India. Sebastian C.H. Kim. New Delhi: Oxford University Press, 2003, 250pp.}

\begin{abstract}
IN Search of Identity is a meticulously researched, clearly written walk through the many-angled history of conversion debates in India. The book offers a rather straightforward overview of Hindu-Christian exchanges from the early nineteenth century to date yet, unlike many other writings in the field, focuses on debate and discordance rather than dialogue. Also distinguishing $\mathrm{Kim}$ is his interest in exploring the problem of conversion on theological rather than practical grounds. His book, as he puts it, aims not so much at exploring why people change their religion but rather why
\end{abstract}

conversion has historically been so problematic. Although the answer is undeniably tied to shifting and conflicting socio-economic, cultural, and political realities, Kim believes the issue cannot be resolved without considering pertinent theological differences between Hindu and Christian traditions. Kim argues that the inter-religious dispute over conversion in India repeatedly reaches an impasse due to failure on both sides to effectively hear the theological and ideological underpinnings of the other's argument. In Search of Identity is an attempt to challenge this impasse by 